\title{
https://helda.helsinki.fi
}

\section{Errors in the Short-Term Forest Resource Information Update}

\section{Luoma, Ville}

Springer International Publishing AG

2017

Luoma , V , Vastaranta , M , Eyvindson , K, Kankare , V , Saarinen , N , Holopainen , M \& Hyyppa , J 2017 , Errors in the Short-Term Forest Resource Information Update . in I Ivan , A Singleton , J Horak \& T Inspektor (eds), The Rise of Big Spatial Data . Lecture Notes in Geoinformation and Cartography, Springer International Publishing AG , pp. 155-166 , GIS Symposium on the Rise of Big Spatial Data , Ostrava , Czech Republic , 16/03/2016 . https://doi.org/10.1007/978-3-

http://hdl.handle.net/10138/308037

https://doi.org/10.1007/978-3-319-45123-7_12

cc_by_nc_nd

acceptedVersion

Downloaded from Helda, University of Helsinki institutional repository.

This is an electronic reprint of the original article.

This reprint may differ from the original in pagination and typographic detail.

Please cite the original version. 


\title{
ERRORS IN THE SHORT-TERM FOREST RESOURCE INFORMATION UPDATE
}

Ville, Luoma ${ }^{1,3}$; Mikko, Vastaranta ${ }^{1,3}$; Kyle, Eyvindson ${ }^{1}$; Ville, Kankare ${ }^{1,3}$; Ninni, Saarinen ${ }^{1,3}$; Markus, Holopainen $^{1,3}$; Juha, Hyyppä ${ }^{2,3}$.

${ }^{1}$ University of Helsinki, Dept. of Forest Sciences, Latokartanonkaari 7, 00014, Helsinki, Finland,

\section{first.last@helsinki.fi}

${ }^{2}$ Finnish Geospatial Research Institute, National Land Survey, Geodeetinrinne 2, 04310 Masala, Finland, first.last@nls.fi

${ }^{3}$ Centre of Excellence in Laser Scanning Research, Finnish Geospatial Research Institute, FI-02431 Masala, Finland

\section{Pre-print of published version \\ Reference:}

Luoma, V., Vastaranta, M., Eyvindson, K., Kankare, V., Saarinen, N., Holopainen M. \& Hyyppä, J. (2017).

Errors in the Short-Term Forest Resource Information Update. In The Rise of Big Spatial Data (pp. 155-166).

Springer International Publishing.

DOI: 10.1007/978-3-319-45123-7_12

\section{Disclaimer:}

The PDF document is a copy of the final version of this manuscript that was subsequently accepted by the journal for publication. The paper has been through peer review, but it has not been subject to any additional copy-editing or journal specific formatting (so will look different from the final version of record, which may be accessed following the DOI above depending on your access situation).

\begin{abstract}
Currently the forest sector in Finland is looking towards the next generation's forest resource information systems. Information used in forest planning is currently collected by using an area-based approach (ABA) where airborne laser scanning (ALS) data are used to generalize field-measured inventory attributes over an entire inventory area. Inventories are typically updated at 10-year interval. Thus, one of the key challenges is the age of the inventory information and the cost-benefit trade-off between using the old data and obtaining new data. Prediction of future forest resource information is possible through growth modelling. In this paper, the error sources related to ALS-based forest inventory and the growth models applied in forest planning to update the forest resource information were examined. The error sources included (i) forest inventory, (ii) generation of theoretical stem distribution, and (iii) growth modelling. Error sources (ii) and (iii) stem from the calculations used for forest planning, and were combined in the investigations. Our research area, Evo, is located in southern Finland. In all, 34 forest sample plots $\left(300 \mathrm{~m}^{2}\right)$ have been measured twice treeby-tree. First measurements have been carried out in 2007 and the second measurements in 2014 which leads to 7 year updating period. Respectively, ALS-based forest inventory data were available for 2007. The results showed that prediction of theoretical stem distribution and forest growth modelling affected only slightly to the quality of the predicted stem volume in short-term information update when compared to forest inventory error.
\end{abstract}

Keywords: Growth modelling, forest planning, GIS, airborne laser scanning, forest inventory

\section{INTRODUCTION}

Accuracy of forest resource information has a decisive impact to decision making concerning forest management and wood procurement. Forest inventory information is used in decision support systems that are further used for making computations of the current state of the forest holding as well as future projections. Errors in input data for the execution of long model chains increase in magnitude and cause significant output errors, e.g. when forest management plans are 
updated (e.g. Ojansuu et al. 2002, Haara \& Korhonen 2004, Haara 2005, Vastaranta et al. 2010, Holopainen et al. 2010a, Holopainen et al. 2010b). The longer the reference period, the larger the output errors; thus, inaccurate input data are especially problematic in forestry yield value determination. In addition, inaccurate input data cause significant losses in forest planning and forest silviculture as the timing of various treatments starts to differ from the optimal timings (e.g. Eid 2000, Eid et al. 2004, Holopainen \& Talvitie 2006, Holopainen et al. 2009).

Airborne laser scanning (ALS) has been generalized as a technique used for forest inventory with an aim for collecting information for forest planning. The applied method is known as area-based approach (ABA). In ABA, ALS data are used to generalize field-measured forest inventory attributes over an entire inventory area. ABA has provided accuracies ranging between $10 \%$ and $27 \%$ for the mean stem volume at stand- or plot-level (e.g. Næsset et al. 2004, White et al. 2013). In ABA, forest inventory attributes, such as species-specific stem volume (V), basal-area (G), Lorey's height (Hg), basal-area weighted mean diameter $(\mathrm{Dg})$, and stem number $(\mathrm{N})$ are predicted for grid cells covering the entire inventory area. However, models used in forest-planning simulation (including attribute update) require measured or estimated stem diameter distributions that are not directly inventoried. Thus, stem diameter distributions are typically formed by predicting/recovering parameters of some theoretical distribution function such as the probability functions of beta, Weibull or Johnson SB distributions based on the forest inventory attributes (Kilkki et al. 1989, Maltamo \& Kangas 1998, Siipilehto 1999, Kangas \& Maltamo 2000, Holopainen et al. 2010c). Then, forest growth modelling is done at tree-level by using growth models for basal-area and height (Hynynen et al. 2002). In this way, forest inventory attribute updating systems that are based on tree-level models are subject to (1) inventory errors, (2) errors in the predicted stem diameter distribution, and (3) errors in the growth modelling.

Our objective was to analyse the effects of these error sources on the short-term forest inventory attribute update in boreal managed forest conditions. The analyses of the error sources were partitioned into two parts. The first part dealt with the errors related to the forest inventory using ABA. The second part dealt with the effect of stem distribution prediction error and growth modelling error. The overall aim related to the study is to develop methods for updating grid-level forest inventory attributes for forest management planning purposes.

\section{MATERIAL AND METHODS}

\section{Study area}

The 5 by $5 \mathrm{~km}$ study area is located in Evo, southern Finland which belongs to the southern boreal forest zone. It consists of approximately 2000 ha of mainly managed boreal forest having an average stand size slightly less than 1 ha. The elevation of the area varies from $125 \mathrm{~m}$ to $185 \mathrm{~m}$ above sea level. Scots pine (Pinus sylvestris L.) and Norway spruce (Picea abies (L.) H.Karst.) were the dominant tree species in the study area contributing $49 \%$ and $28 \%$ of the total stem volume, respectively. The share of deciduous trees was $23 \%$ of the total stem volume. 


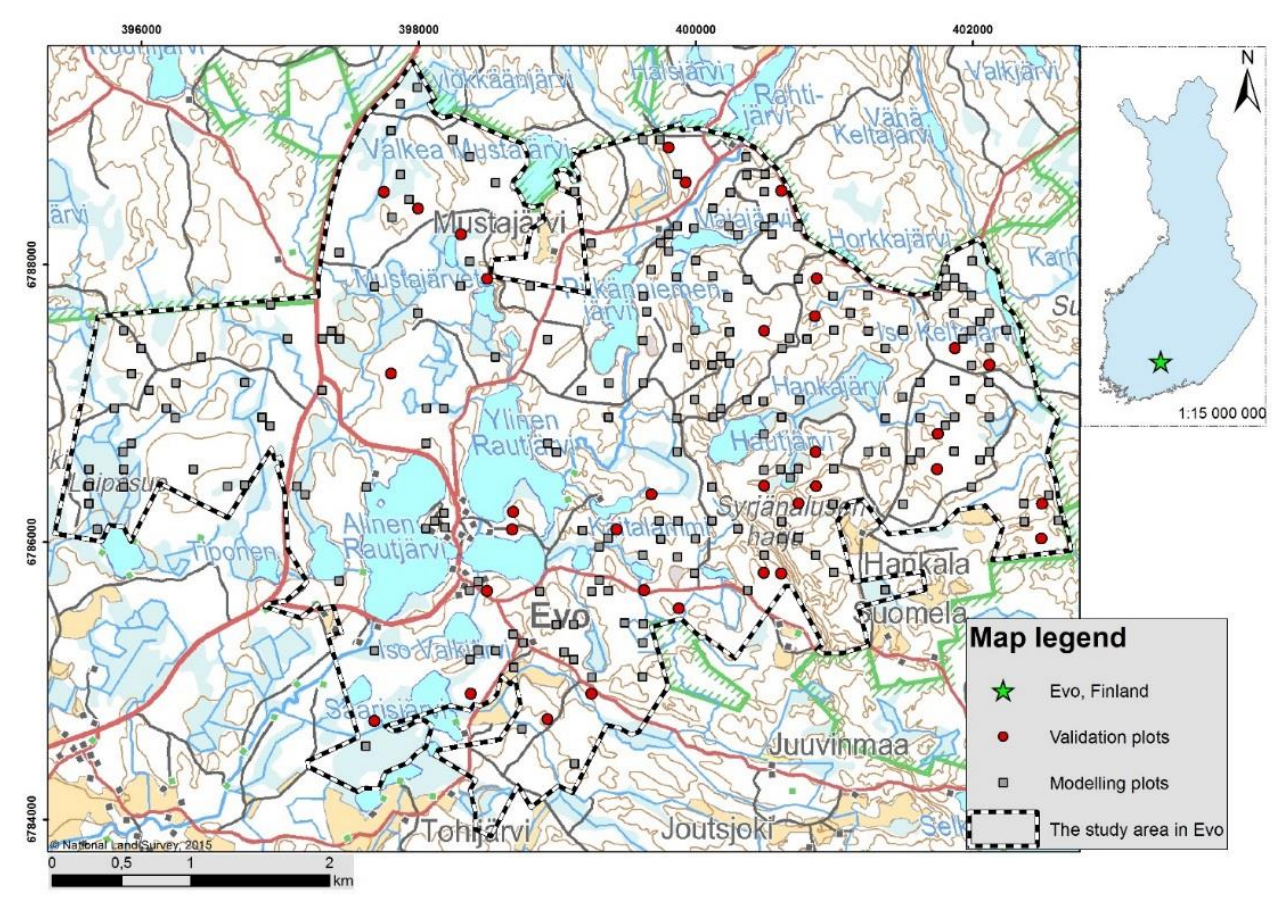

Fig. 1. Map of the study area containing the modelling $(n=246)$ and validation $(n=34)$ plots used in the study.

\section{Field data from 2007 and 2014}

Field measurements were undertaken in summer 2007 on 246 circular plots (modelling plots) with 9.77 m radius. The modelling plots were selected based on pre-stratification of existing stand inventory data (Kankare et. al 2013). All trees having a diameter-at-breast-height (DBH) of over $5 \mathrm{~cm}$ were tallied and tree height, $\mathrm{DBH}$, and species were recorded. Tree heights were measured using Vertex clinometers as DBH was measured with steel callipers. The stem volumes were calculated with standard Finnish species-specific stem volume models (Laasasenaho 1982). The plot-level data were obtained by summing the tree data. From the 246 modelling plots, a further sample of 34 plots was selected in year 2014 to be used as validation plots in this study. The validation plots were distributed over the study area among the modelling plots to cover all the various site types, stand development classes, and tree species. The unnatural changes to modelling plots, such as clear-cuts or thinnings, limited the number of validation plots available. The descriptive statistics of modelling plots $(n=246)$ and validation plots $(n=34)$ are summarized in Table 1 . The plot centres were measured with a Trimble's GEOXM 2005 Global Positioning System (GPS) device (Trimble Navigation Ltd.,Sunnyvale, CA, USA), and the locations were post-processed with local base station data, resulting in an average error of app. $0.6 \mathrm{~m}$.

The 34 validation plots were re-measured in 2014 with the exactly similar plot set up as year 2007. Again all trees on the plot with DBH over $5 \mathrm{~cm}$ were measured and $\mathrm{DBH}$, tree height and species were recorded. The sample plots were located based on the recorded coordinates for the plot centres from 2007 measurements. The plot centres were even marked with signposts during the 2007 measurements so that the exact plot centre could be found for re-measurements. The descriptive statistics for sample plots measured on year 2014 are shown in Table 2. 
Table 1. Field inventoried mean attributes of modelling plots $(n=246)$ and validation plots $(n=34)$ from 2007. Standard deviations are provided in the parenthesis. The validation plots were also included in modelling plots.

\begin{tabular}{|c|c|c|c|c|c|c|}
\hline \multicolumn{7}{|c|}{ Field inventory 2007} \\
\hline \multirow{5}{*}{$\begin{array}{l}\text { Modelling plots } \\
(n=246)\end{array}$} & & $\mathrm{V}, \mathrm{m}^{3} / \mathrm{ha}$ & $\mathrm{G}, \mathrm{m}^{2} / \mathrm{ha}$ & $\mathrm{N}, / \mathrm{ha}$ & $\mathrm{Dg}, \mathrm{cm}$ & $\mathrm{Hg}, \mathrm{m}$ \\
\hline & Scots pine & $70.6(86.1)$ & $7.9(8.5)$ & $282(358)$ & $23.2(9.6)$ & $17.7(6)$ \\
\hline & Norway spruce & $67.9(95.9)$ & $7.3(8.6)$ & $361(344)$ & $17.8(10.2)$ & $14(7.4)$ \\
\hline & Deciduous & $48.2(56)$ & $6(6.4)$ & $386(422)$ & $17.8(9.2)$ & $16.1(5.5)$ \\
\hline & All & $186.6(110.4)$ & $21.2(9.5)$ & $1029(618)$ & & \\
\hline \multirow{5}{*}{$\begin{array}{l}\text { Validation plots } \\
(n=34)\end{array}$} & & $\mathrm{V}, \mathrm{m}^{3} / \mathrm{ha}$ & $\mathrm{G}, \mathrm{m}^{2} / \mathrm{ha}$ & $\mathrm{N}, /$ ha & $\mathrm{Dg}, \mathrm{cm}$ & $\mathrm{Hg}, \mathrm{m}$ \\
\hline & Scots pine & $110.8(116.2)$ & $12(10.4)$ & $359(326)$ & $25(11.1)$ & $18.6(5.6)$ \\
\hline & Norway spruce & $63.3(119.6)$ & $6.8(10.3)$ & $399(456)$ & $15.3(10.3)$ & $12.5(7.7)$ \\
\hline & Deciduous & $56.4(78.2)$ & $6.7(8.2)$ & $415(541)$ & $16.7(8)$ & $15.9(5.2)$ \\
\hline & All & $230.4(125.5)$ & $25.4(9.5)$ & $1173(750)$ & & \\
\hline
\end{tabular}

Table 2. Field inventoried mean attributes of validation plots $(n=34)$ from 2014. Standard deviations are provided in the parenthesis.

\begin{tabular}{llllll}
\hline \multicolumn{5}{c}{ Field inventory 2014} \\
\hline Scots pine & $\mathrm{V}, \mathrm{m}^{3} / \mathrm{ha}$ & $\mathrm{G}, \mathrm{m}^{2} / \mathrm{ha}$ & $\mathrm{N}, / \mathrm{ha}$ & $\mathrm{Dg}, \mathrm{cm}$ & $\mathrm{Hg}, \mathrm{m}$ \\
Norway spruce & $131.1(115.1)$ & $13.1(10.5)$ & $340(317)$ & $26.7(10.6)$ & $20.6(4.8)$ \\
Deciduous & $75.4(119.2)$ & $7.9(10.1)$ & $458(479)$ & $17.2(10.4)$ & $14.4(7.2)$ \\
All & $63.4(88.5)$ & $7.1(9)$ & $433(540)$ & $16(7)$ & $16.5(4.8)$ \\
\hline$n=34$ plots & $270(105.8)$ & $28(8.4)$ & $1231(814)$ & & \\
\hline
\end{tabular}

\section{Remote sensing-based forest inventory from 2007}

The remote sensing data were collected in midsummer 2006. ALS was performed using Optech ALTM3100C-EA system operating with a pulse rate of $100 \mathrm{kHz}$. Data were acquired at a flight altitude of $1900 \mathrm{~m}$ resulting in an average pulse density of 1.3 pulses per square meter in non-overlapping areas and a footprint of $70 \mathrm{~cm}$ in diameter. The system was configured to record up to four returns per pulse, i.e. first, last, only, and intermediate. Reported positioning accuracy was $40 \mathrm{~cm}$ and $15 \mathrm{~cm}$ for horizontal and vertical direction respectively. Same-date aerial photographs were obtained with a digital camera and the photographs were orthorectified, resampled to pixel size of $0.5 \mathrm{~m}$ and mosaicked to a single image covering the entire data. Near-infrared (NIR), red (R) and green (G) bands were available.

ALS data were first classified into ground or non-ground points using the TerraScan (TerraSolid, Helsinki, Finland) based on the method explained in Axelsson (2000). A digital terrain model (DTM) was then calculated using classified ground points. Laser heights above ground (normalized height or canopy height) were calculated by subtracting ground elevation from corresponding laser measurements. The expected accuracy of the ALS-derived DTM varies in boreal forest conditions by around 10-50 cm (Hyyppä et al. 2009). Canopy heights closed to zero are the ground returns and those greater than $2 \mathrm{~m}$ are considered as vegetation returns. The data between them are considered as returns from ground vegetation or bushes. Only the returns from vegetation were used for feature extraction. Statistical metrics describing canopy structure were extracted for the sample plots (radius $9.77 \mathrm{~m}$ ) following suggestions by White et al. (2013). Also several statistical and textural features were extracted from the aerial photographs, such as the means and standard deviations of spectral values (Holopainen et al. 2008). The Haralick textural features (Haralick et al. 1973; Haralick 1979) were derived from the spectral values. 
Species specific basal area (G), basal area-weighted mean diameter (Dg), Lorey's height (Hg), stem volume (V), and number of stems per hectare $(\mathrm{N})$ were predicted by means of remote sensing metrics using random forest (RF, Breiman 2001) based k nearest-neighbor (NN) approach. Forest inventory attributes measured in the field were used as target observations, and plot-specific metrics derived from remote sensing data sets were used as predictors. The RF approach was applied in the search of nearest neighbors. In the RF method, several regression trees are generated by drawing a replacement from two-thirds of the data for training and one-third for testing for each tree. The samples that are not included in training are called out-of-bag samples, and they can act as a testing set in the approach. The measure of nearness in RF is defined based on the observational probability of ending up in the same terminal node in classification. The R statistical computing environment (R Core Team) and yalmpute library (Crookston and Finley 2008) were applied in the predictions. In the present study, 1200 regression trees were generated, and the square root of the number of predictor variables was picked randomly at the nodes of each regression tree. The number of neighbors was set to one to keep the original variance in the data (see, e.g., Hudak et al. 2008, Franco-Lopez et al. 2001). Prior to the final modeling, RF was used to reduce the number of predictor variables. The aim of the variable reduction was to build up parsimonious models that are capable of accurate prediction. In the variable selection, RF iterated 100 times per model and the best variables based on their importance for each model were selected. Then, only the most important variables based on the results were used for the final imputations. The used predictors were the vegetation ratio from first and last pulses, the heights where 30 and 90 percent of first laser returns and 30 percent of last returns had been received, mean height in the pixel window, local homogeneity $90^{\circ}$ of height, the average NIR and standard deviation of NIR.

To improve the accuracy of the species specific estimates, the sample plots were divided into four strata according to existing stand register information. The first stratum included Scots pine dominated stands, the second stratum Norway spruce dominated stands, the third stratum included stands dominated by deciduous trees and the fourth stratum had stands with approximately equal share of pine and spruce trees with a mixture of deciduous trees. The first stratum comprised 92 sample plots, the second 56, the third 41 and the fourth 57 sample plots respectively. The final imputations were carried out for each stratum separately.

\section{Simulation of forest growth}

The forest attribute update calculations from 2007 to 2014 were carried out using SIMO software (SIMO simulation framework, Rasinmäki et al. 2009). SIMO is a common platform for various stand simulators including Finnish tree- and stand-level simulators. The simulation logic is described in XML documents (eXtensible Markup Language) and lends itself to be easily adapted for various types of calculations. The non-spatial tree-level growth models found in SIMO are, for the most part, the same as those found in the MELA2002 and MOTTI simulators (Hynynen et al. 2002; Salminen et al. 2005). They include growth models for all sites and tree species in Finland, including separate models for peatlands. The tree-level simulator can be used to simulate the growth of either sample trees measured in the field or descriptive trees generated on the basis of a theoretical diameter/height distribution. The simulation is performed at the singletree level. The statistics for the strata and stands are derived as the sums and means of the simulated tree properties.

\section{Evaluation of the errors}

The accuracy of the ABA and updated stem volumes estimates was evaluated by calculating bias and root-mean-square error (RMSE) for three different alternatives (Table 3):

$$
\begin{gathered}
\text { BIAS }=\frac{\sum_{i=1}^{n}\left(y_{i}-\hat{y}_{i}\right)}{n} \\
B I A S \%=100 * \frac{B I A S}{\bar{y}}
\end{gathered}
$$




$$
\begin{aligned}
& R M S E=\sqrt{\frac{\sum_{i=1}^{n}\left(y_{i}-\hat{y}_{i}\right)^{2}}{n}} \\
& R M S E \%=100 * \frac{R M S E}{\bar{y}}
\end{aligned}
$$

where $n$ is the number of plots, $y_{i}$ is the observed value (by tree-wise measurements from 2014) for plot $i, \hat{y}_{i}$ is updated attribute for plot i and $\bar{y}_{i}$ is the observed mean of the species-specific - or total stem volume.

Table 3. Principles used in the error analyses.

\begin{tabular}{llll}
\hline Alternative & Source of error & Input data & Reference data \\
\hline 1 & Inventory error & $\begin{array}{l}\text { Species-specific stem volumes } \\
\text { derived from ABA }\end{array}$ & $\begin{array}{l}\text { Species-specific stem volumes derived } \\
\text { from field measurements from 2007 }\end{array}$ \\
2 & $\begin{array}{l}\text { Prediction of theoretical } \\
\text { stem diameter } \\
\text { distribution and growth } \\
\text { modelling error } \\
\text { Combined errors }\end{array}$ & $\begin{array}{l}\text { Species-specific stem volumes } \\
\text { derived from field measurements } \\
\text { from 2007 }\end{array}$ & $\begin{array}{l}\text { Species-specific stem volumes derived } \\
\text { from field measurements from 2014 }\end{array}$ \\
& $\begin{array}{l}\text { Species-specific stem volumes } \\
\text { derived from ABA }\end{array}$ & $\begin{array}{l}\text { Species-specific stem volumes derived } \\
\text { from field measurements from 2014 }\end{array}$ \\
\hline
\end{tabular}

\section{RESULTS AND DISCUSSION}

The results from the remote sensing data based prediction of forest inventory attributes in year 2007 are presented in Table 4. For the validation plots $(n=34)$ the empirical $95 \%$ interval of total stem volume was between $42.4 \mathrm{~m}^{3} / \mathrm{ha}$ and $431.2 \mathrm{~m}^{3} / \mathrm{ha}$. The species specific empirical $95 \%$ intervals for stem volume were for pine from 0 to $266.4 \mathrm{~m}^{3} / \mathrm{ha}$, for spruce from 0 to $239.0 \mathrm{~m}^{3} /$ ha and for deciduous trees from 0.5 to $225.7 \mathrm{~m}^{3} /$ ha, respectively. 
Table 4. Mean values for predicted forest inventory attributes using ABA. Standard deviations are provided in the parenthesis.

\begin{tabular}{llllll}
\hline \multicolumn{6}{l}{ ABA predicted forest inventory attributes 2007} \\
\hline Scots pine & $104.4(85)$ & $11.5(8.5)$ & $367(292)$ & $22.5(8.9)$ & $17.8(6.4)$ \\
Norway spruce & $49.8(76.9)$ & $5.7(7.3)$ & $382(361)$ & $14.4(8.4)$ & $11.6(6.4)$ \\
Deciduous & $56.6(67.5)$ & $6.7(6.9)$ & $483(512)$ & $15.7(6.5)$ & $15.2(5.8)$ \\
Total & $210.9(108.1)$ & $23.8(8.8)$ & $1231(685)$ & & \\
\hline$n=34$ plots & & & & &
\end{tabular}

The RMSE of forest inventory for total stem volume was $25.2 \%$ as the bias was $8.5 \%$ (Table 5 ). Species-specific RMSEs and biases varied from $80.0 \%$ to $134.3 \%$ and from $-0.5 \%$ to $21.3 \%$, respectively. At the sample plot-level the range in inventory error (difference) was from $-83.6 \mathrm{~m}^{3} /$ ha to $167.4 \mathrm{~m}^{3} / \mathrm{ha}$ (Fig. 2). Based on Hudak et al. (2008) and Franco-Lopez et al. (2001) increasing the number of neighbors would improve the prediction accuracy. However, inventory RMSEs are in line with the previous studies in the same study area (Holopainen et al. 2010a, Yu et al. 2010, Vastaranta et al. 2011, Vastaranta et al. 2012, Vastaranta et al. 2013, Kankare et al. 2015). Controversially, ABA inventory in this study included bias. Bias can be resulted from the rather limited number of validation plots $(n=34)$ as well as from slight differences in forest inventory attributes measured from modelling plots used in ABA compared to validation plots (See Table 1). For

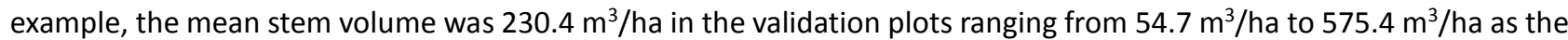
respective numbers from modelling plots were $186.6 \mathrm{~m}^{3} / \mathrm{ha}$ (mean), $0 \mathrm{~m}^{3} / \mathrm{ha}(\min )$ and $575.4 \mathrm{~m}^{3} / \mathrm{ha}(\mathrm{max})$. To avoid more bias number of nearest neighbors was chosen to be 1.

Prediction of stem diameter distribution and growth modelling errors caused $6.7 \%$ bias and $18.8 \%$ RMSE to the updated stem volume. Species-specific RMSEs and biases varied from $23.1 \%$ to $65.9 \%$ and from $5.5 \%$ to $9.0 \%$, respectively. The RMSEs are lower than the ones for the ABA forest inventory of year 2007. Based on the previous studies (Vastaranta et al. 2010, Holopainen et al. 2010c) it can be assumed that the majority of this error is caused by the growth modelling and only a minor component from the generated stem distribution. Although, error of predicting stem diameter distribution cannot be separated from the growth modelling error in this study, it has been shown that its effect is marginal in this kind of study design (e.g. Holopainen et al. 2010c). At the sample plot-level the range in error of prediction of stem distribution and growth modelling error (difference) was from $-134.7 \mathrm{~m}^{3} / \mathrm{ha}$ to $93.7 \mathrm{~m}^{3} / \mathrm{ha}$ (Fig. 3).

Combined error of forest inventory, prediction of theoretical stem distribution and forest growth modelling caused 13.1\% bias and $24.6 \%$ RMSE to the updated stem volume. Species-specific RMSEs and biases varied from $65.8 \%$ to $109.2 \%$ and from $3.7 \%$ to $26.7 \%$, respectively. At the sample plot-level the range in combined errors was from -95.3 $\mathrm{m}^{3} /$ ha to $156.8 \mathrm{~m}^{3} /$ ha (Fig. 4).

Compared to attribute update from error free data (errors of prediction of stem distribution and growth modelling), it can be seen that biases are 5-15 percentage points larger for total stem volume as well as for species specific stem volumes when all the error sources are combined. Similarly, RMSE for total stem volume is roughly 10 percentage points larger. Species-specific errors increase more. Accuracy of the species-specific stem volumes is ranging from $80.0 \%$ to $134.3 \%$ with ABA (inventory error) and thus it can be expected that these errors shift to outputs of the update process. 
Table 5. Effect of inventory error on predicted species-specific stem volumes as well as on the total stem volume (V) on the validation plots.

\begin{tabular}{|c|c|c|c|c|c|}
\hline Error source & & $\mathbf{V}$ & V_pine & V_spruce & V_dec \\
\hline \multirow[t]{4}{*}{ Forest inventory error } & RMSE, $\mathrm{m}^{3} / \mathrm{ha}$ & 58.0 & 88.7 & 80.8 & 75.7 \\
\hline & RMSE-\% & $25.2 \%$ & $80.0 \%$ & $127.6 \%$ & $134.3 \%$ \\
\hline & Bias, $\mathrm{m}^{3} / \mathrm{ha}$ & 19.6 & 6.4 & 13.5 & -0.3 \\
\hline & Bias-\% & $8.5 \%$ & $5.7 \%$ & $21.3 \%$ & $-0.5 \%$ \\
\hline \multirow{4}{*}{$\begin{array}{l}\text { Growth modelling and } \\
\text { prediction of theoretical stem } \\
\text { diameter distribution error }\end{array}$} & RMSE, $\mathrm{m}^{3} / \mathrm{ha}$ & 50.7 & 35.4 & 17.4 & 41.8 \\
\hline & RMSE-\% & $18.8 \%$ & $27.0 \%$ & $23.1 \%$ & $65.9 \%$ \\
\hline & Bias, $\mathrm{m}^{3} / \mathrm{ha}$ & 18.1 & 7.8 & 6.8 & 3.5 \\
\hline & Bias-\% & $6.7 \%$ & $5.9 \%$ & $9.0 \%$ & $5.5 \%$ \\
\hline \multirow{4}{*}{$\begin{array}{l}\text { Combined error of forest } \\
\text { inventory, prediction of } \\
\text { theoretical stem diameter } \\
\text { distribution and forest growth } \\
\text { modelling. }\end{array}$} & RMSE, $\mathrm{m}^{3} / \mathrm{ha}$ & 66.3 & 86.3 & 82.4 & 67.4 \\
\hline & RMSE-\% & $24.6 \%$ & $65.8 \%$ & $109.2 \%$ & $106.3 \%$ \\
\hline & Bias, $\mathrm{m}^{3} / \mathrm{ha}$ & 35.5 & 13.0 & 20.1 & 2.3 \\
\hline & Bias-\% & $13.1 \%$ & $9.9 \%$ & $26.7 \%$ & $3.7 \%$ \\
\hline
\end{tabular}

Field measured stem volume 2007 - ABA inventory 2007

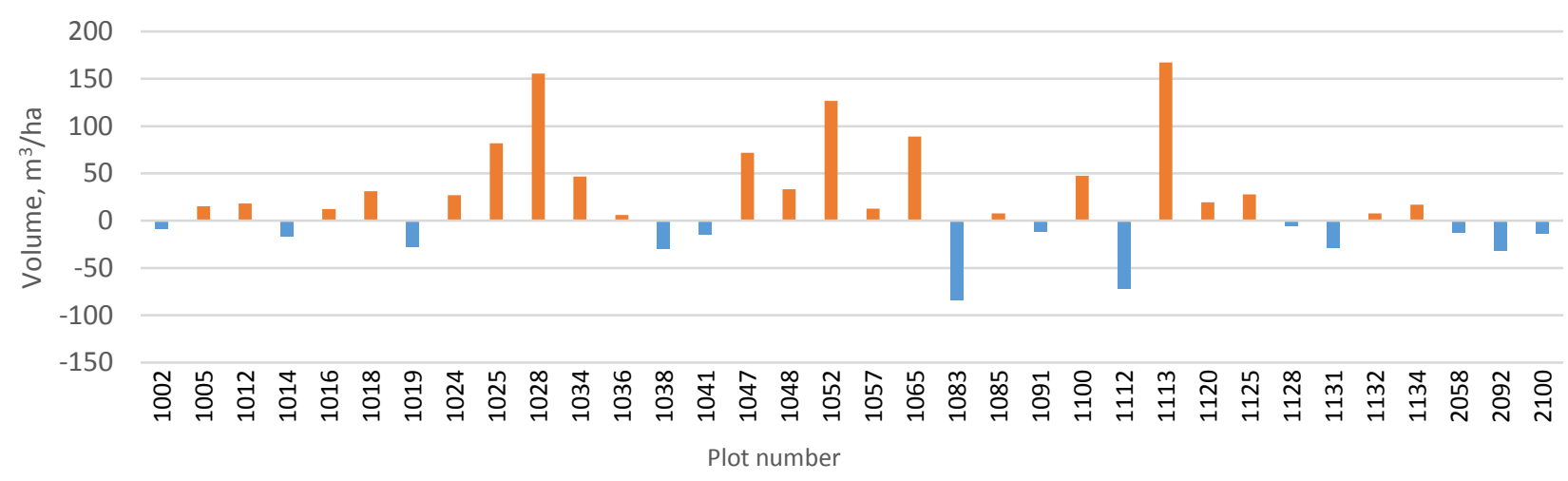

Fig. 2. Field measured stem volume ( $\left.\mathrm{m}^{3} / \mathrm{ha}\right)$ (2007) compared to stem volume estimate based on $A B A(2007)$.

Field measured stem volume 2014 - Updated field measured stem volume 2007

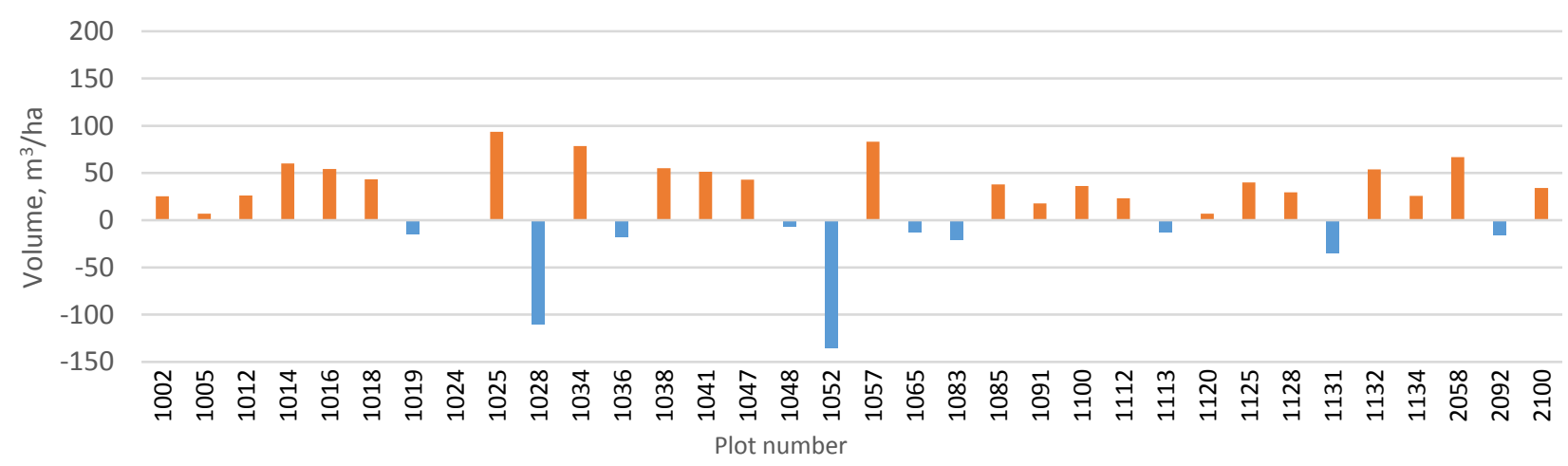

Fig. 3. Field measured stem volume ( $\mathrm{m}^{3} / \mathrm{ha}$ ) (2014) compared to field measured stem volume from 2007 updated to year 2014. The update was done by utilizing growth models. 


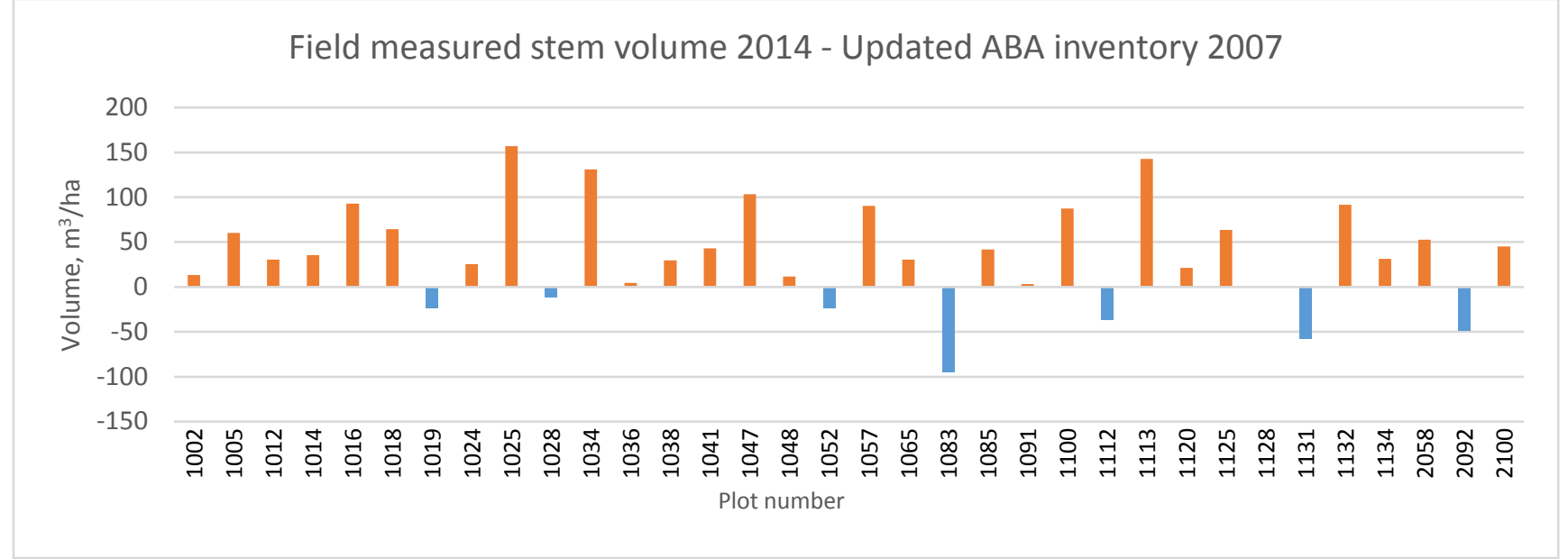

Fig. 4. Field measured stem volume ( $\mathrm{m}^{3} / \mathrm{ha}$ ) (2014) compared to stem volume estimate based on ABA from 2007 updated to year 2014. The update was done by utilizing growth models.

\section{CONCLUSIONS}

The objective here was to analyse the effects of error sources on the short-term forest inventory attribute update in boreal managed forest conditions. The analyses of the error sources were partitioned into two parts. The first part dealt with the errors related to the forest inventory using ABA. The second part dealt with the effect of stem distribution prediction error and growth modelling error. The results showed that prediction of theoretical stem distribution and forest growth modelling affected only slightly to the quality of the predicted stem volume in short-term information update. The results of our study confirm that the quality of the input data is the most effective error source in shortterm forest information update. Thus, further studies are required especially for obtaining species-specific forest inventory information more accurately.

\section{ACKNOWLEDGEMENTS}

Our study was made possible by financial aid from the Finnish Academy project Centre of Excellence in Laser Scanning Research (CoE-LaSR, decision number 272195). We also wish to thank M.Sc. Risto Viitala at the HAMK University of Applied Sciences for organizing part of the field data collections.

\section{REFERENCES}

Axelsson, P. (2000). DEM generation from laser scanner data using adaptive TIN models. In: International Archives of Photogrammetry and Remote Sensing, Amsterdam, 33(B4), 110-117.

Breiman, L. (2001). Random forests. Machine Learning, 45(1), 5-32.

Crookston, N.L. and Finley A.O. (2008). yalmpute: an R package for kNN imputation. Journal of Statistical Software 23(10), $1-16$.

Eid, T. (2000). Use of uncertain inventory data in forestry scenario models and consequential incorrect harvest decisions. Silva Fennica 34, 89-100.

Eid, T., Gobakken, T. and Næsset, E. (2004) Comparing stand inventories for large areas based on photo-interpretation and laser scanning by means of cost-plus-loss analyses. Scandinavian Journal of Forest Research,19, 512-523. 
Franco-Lopez, H., Ek, A.R., Bauer, M.E. (2001). Estimation and mapping of forest stand density, volume, and cover type using k-nearest neighbors method. Remote Sensing of Environment, 77(3), 251-274.

Haara, A. (2005) The uncertainty of forest management planning data in Finnish non-industrial private forestry. Doctoral thesis. Dissertationes Forestales 8. 34 p.

Haara, A. and Korhonen, K. (2004) Kuvioittaisen arvioinnin luotettavuus. Metsätieteen aikakauskirja 4, 489-508. (in Finnish).

Haralick, R., Shanmugan, K. and Dinstein, I. (1973) Textural features for image classification. IEEE Transactions on Systems, Man and Cybernetics, 3(6), 610-621.

Haralick, R. (1979) Statistical and structural approaches to texture. Proceedings of the IEEE, 67(5), 786-804.

Holopainen, M., Talvitie, T. (2006) Effects of data acquisition accuracy on timing of stand harvests and expected net present value. Silva Fennica, 40(3), 531-543.

Holopainen, M., Haapanen, R., Tuominen, S. and Viitala, R. (2008) Performance of airborne laser scanning- and aerial photograph-based statistical and textural features in forest variable estimation. In Hill, R., Rossette, J. and Suárez, J. 2008. Silvilaser 2008 proceedings, 105-112.

Holopainen, M., Vastaranta, M., Mäkinen, A., Rasinmäki, J., Hyyppä, J., Hyyppä, H. and Kaartinen, H. (2009) The use of tree level ALS data in forest management planning simulations. The Photogrammetric Journal of Finland, 21(2), 13-24.

Holopainen, M., Mäkinen, A., Rasinmäki, J., Hyyppä, J., Hyyppä, H., Kaartinen, H. and Kangas, A. (2010a). Effect of treelevel airborne laser-scanning measurement accuracy on the timing and expected value of harvest decisions. European Journal of Forest Research, 129(5), 899-907.

Holopainen, M., Mäkinen, A., Rasinmäki, J., Hyytiäinen, K., Bayazidi, S., Vastaranta, M. and Pietilä, I. (2010b). Uncertainty in forest net present value estimations. Forests, 1(3), 177-193.

Holopainen, M., Mäkinen, A., Rasinmäki, J., Hyytiäinen, K., Bayazidi, S. and Pietilä, I. (2010c) Comparison of various sources of uncertainty in stand-level net present value estimates. Forest Policy and Economics, 12(5), 377-386.

Hudak, A.T., Crookston, N.L., Evans, J.S., Hall, D.E. and Falkowski, M.J. (2008) Nearest neighbor imputation of specieslevel, plot-scale forest structure attributes from LiDAR data. Remote Sensing of Environment, 112, 2232-2245.

Hynynen, J., Ojansuu, R., Hökkä, H., Siipilehto, J., Salminen, H. and Haapala, P. (2002) Models for predicting stand development in MELA system. Finn For Res Inst Res Pap 835.

Hyyppä, J., Hyyppä, H., Yu, X., Kaartinen, H., Kukko, A., and Holopainen, M. (2009). Forest inventory using small-footprint airborne LiDAR. Topographic laser ranging and scanning: Principles and processing, 335-370.

Kangas, A. and Maltamo, M. (2000) Performance of percentile based diameter distribution prediction and Weibull method in independent data sets. Silva Fennica 34, 381-398.

Kankare, V., Vastaranta, M., Holopainen, M., Räty, M., Yu, X., Hyyppä, J., Hyyppä, H., Alho, P., Viitala, R. (2013) Retrieval of forest aboveground biomass and volume with airborne scanning LiDAR. Remote Sensing 5(5), 2257-2274.

Kankare, V., Vauhkonen, J., Holopainen, M., Vastaranta, M., Hyyppä, J., Hyyppä, H. and Alho, P. (2015) Sparse Density, Leaf-Off Airborne Laser Scanning Data in Aboveground Biomass Component Prediction. Forests 6, 1839-1857.

Kilkki, P., Maltamo, M., Mykkänen, R. and Päivinen, R. (1989) Use of the Weibull function in estimating the basal-area diameter distribution. Silva Fennica 23, 311-318. 
Laasasenaho, J. (1982) Taper curve and volume functions for pine, spruce and birch. Communicationes. Institute Forestalis Fenniae 108, 74 p.

Maltamo, M. and Kangas, A.(1998) Methods based on k-nearest neighbour regression in the prediction of basal area diameter distribution. Canadian Journal of Forest Research, 28, 1107-1115.

Næsset, E., Gobakken, T., Holmgren, J., Hyyppä, H., Hyyppä, J., Maltamo, M., Nilsson, M., Olsson, H., Persson, Å. and Söderman, U. (2004) Laser Scanning of Forest Resources: The Nordic Experience. Scand. J. For. Res., 18(19), $482-499$.

Ojansuu, R., Halinen, M. and Härkönen, K. (2002) Metsätalouden suunnittelujärjestelmän virhelähteet männyn esiharvennuskypsyyden määrittämisessä. Metsätieteen aikakauskirja 3/2002, 441-457. (in Finnish).

Rasinmäki, J., Kalliovirta, J. and Mäkinen, A. (2009) SIMO: an adaptable simulation framework for multiscale forest resource data. Comput Electron Agric 66, 76-84.

Siipilehto, J. (1999) Improving the accuracy of predicted basal-area diameter distribution in advanced stands by determining stem number. Silva Fennica 34, 331-349.

Salminen, H., Lehtonen, M. and Hynynen, J. (2005) Reusing legacy FORTRAN in the MOTTI growth and yield simulator. Comput Electron Agric 49, 103-113.

Vastaranta, M., Ojansuu, R. and Holopainen, M. (2010) Puustotunnusten laskennallisen ajantasaistuksen luotettavuus - tapaustutkimus Pohjois-Savossa. Metsätieteen aikakauskirja 4/2010, 367-381. (in Finnish)

Vastaranta, M., Holopainen, M., Yu, X., Haapanen, R., Melkas, T., Hyyppä, J. and Hyyppä, H. (2011) Individual tree detection and area-based approach in retrieval of forest inventory characteristics from low-pulse airborne laser scanning data. The Photogrammetric Journal of Finland, 22(2), 1-13.

Vastaranta, M., Kankare, V., Holopainen, M., Yu,X., Hyyppä, J. and Hyyppä, H. (2012) Combination of individual tree detection and area-based approach in imputation of forest variables using airborne laser data. ISPRS Journal of Photogrammetry and Remote Sensing, 67, 73-79.

Vastaranta, M., Wulder, M.A., White, J.C., Pekkarinen, A., Tuominen, S., Ginzler, C., Kankare, V., Holopainen, M., Hyyppä, J. and Hyyppä, H. (2013) Airborne laser scanning and digital stereo imagery measures of forest structure: Comparative results and implications to forest mapping and inventory update. Canadian Journal of Remote Sensing, 39(5), 382-395.

White, J.C., Wulder, M.A., Varhola, A., Vastaranta, M., Coops, N.C., Cook, B.D., Pitt, D. and Woods, M. (2013) A best practices guide for generating forest inventory attributes from airborne laser scanning data using the area-based approach. Information Report FI-X-10. Natural Resources Canada, Canadian Forest Service, Canadian Wood Fibre Centre, Pacific Forestry Centre, Victoria, BC. 50 p.

Yu, X., Hyyppä, J., Holopainen, M. and Vastaranta, M. (2010) Comparison of Area-Based and Individual Tree-Based Methods for Predicting Plot-Level Forest Attributes. Remote Sens. 2, 1481-1495 